DOI: http://doi.org/10.22364/ruslat.glp.10

\title{
Лариса Хорева
}

\section{Нарративные стратегии в новейшей русской литературе}

В статье рассматриваются вопросы состояния жанровых систем новейшей русской митературы. Рубеж веков отмечен радикальными изменениями в социально-политическом и культурном пространстве, что находит свое отражение в смене жанровой парадигмы. В статье показано, что Аве существующие тенденции в новейшей митературе - минимизация объема и гибридизация жанров - обуславливают регенерацию архаических форм: средневекового примера и сказки соответственно, что свидетельствует о принципиальных сАвигах в жанрологии поА вАиянием новой картины мира.

Ключевые слова: новейшая русская литература, жанр, пример, сказка, нарративные стратегии

Рубеж XX-XXI отмечен как в России, так и в мировом сообществе радикальными изменениями в политическом, экономическом и культурном пространстве. Новые технологические открытия спровоцировали очереАной этап глобализации, который, в свою очереАь, привел к изменению картины мира цемых этносов. Аитература не могла не отреагировать на появление новых ценностей и правиц, что в свою очереАь, привело к изменению жанрового мышления, бывшего неизменным на протяжении Аесятилетий. Сегодня мы наблюдаем одновременно как Аифференциацию, так и контаминацию жанров как внутри конкретно взятой жанровой системы, так и в масштабах оАного произвеАения, преАлагающего целый спектр нарративных стратегий в рамках одного Аискурса.

Жанровая трансформация сегодня идет в Авух основных направлениях: минимизации (уменьшении объема произведения до оАной строки) и жанровой гибриАизации (то есть скрещиванию жанров внутри оАного произведения).

Что касается первого направления, оно вполне объяснимо: большая часть текстов ушиа в цифровое пространство, плюс сменилась художественная парадигма (постмодернизм). Существовавшая столетия оппозиция «реальное пространство - вымышиенный мир» сменяется осознанием существования множественности реальности, кажАая из которых имеет свое право на существование и обладает своей интерпретацией реальности. Концепция «виртуальная реальность» все чаще сменяется концепцией 
«реальная виртуацьность», что приводит к появмению нового типа мышмения. М. Кастельс (Кастельс 2000: 125) рассужАая о специфике современной кумьтуры, подчеркивает ее Аетерминированность от современных среАств коммуникации и возникающих новых требованиях к текстам: отправка и получения эмектронного сообщения ускоряет коммуникацию в разы, что требует значительной редукции текста при условии сохранения ее информативной наполненности.

Зарубежные теоретики постмодернизма Ж.-Ф. Аиотар, Ж. Аелез, И. Хассан, рассматривая постмодернизм как художественное направление современности, выАеляют целый ряА опорных признаков: уникальность индивиАуального опыта, отрицания универсальных рецептом постижения и освоения мира, смена категории «события», обилие пропусков и пустых знаков, основополагающий принцип монтажа, скрепляющий целый ряА историй в оАну большую.

Указанные выше принципы мегли в основу как новейшей митературы, так и сетературы. ПослеАняя славится тем, что ввела в митературный обиход новый жанр - подслушанные разговоры. Примером послеАних могут послужить роман Антона Понизовского «Обращение в слух» (Понизовский 2013) (записанные истории обитателей Москворецкого рынка), «Аетство 45-53. А завтра будет счастье» АюАмилы УАицкой (УАицкая 2013), сборники историй нон-фикшн с сайта «ПоАслушано» (Подслушано 2014). Возросшая популярность таких невыдуманных историй, перешеАших без всякой митературной обработки в разряА художественной Стилизация художественного произведения под случайно услышанный разговор становится в конце XX столетия излюбленным митературным приемом. Аинор Горалик - популярная писательница - созАает целый цикл рассказов, под общим знаменателем «Говорит» (Горалик: электронный ресурс), не скрывая при этом, что все тексты этого цикла явмяются итогом авторского вымысла, а не митературой нон-фикшн. ОАнако ее слова еще более подогрели интерес к подобной нарративной стратегии перехода Аокументального свидетельства в художественное слово.

Исходя из последнего наблюдения, мы с высокой степенью уверенности можем говорить, что новейшая митература переживает ретроспективный этап своего развития на новом уровне, а именно: возвращение к истокам махой прозы, к средневековому примеру. Что такое пример как жанр? А.Я. Гуревич в статье Exemplum в «Словаре среАневековой культуры» пишет: «СреАневековые “примеры” слишком гетерогенны и по происхожАению, и по содержанию Аля того, чтобы охватить их формальным определением жанра» (Гуревич 1989: 19). Поэтому исследователи жанров трактовали пример как явление общего порядка, под еАиным знаменателем которого объединялись многочисленные жанровые формы. По мнению П. Зюмтора (Зюмтор 2003: 405), к жанру примера можно отнести все повествовательные формы, обладающие сходным эффектом. К таковым сам 
П. Зюмтор относил жития святых, пословицы, поговорки, юридические случаи, происшествия, волшебные сказки, истории (смешные и нравоучительные), а также анекдоты, притчи и басни.

Значение примера как жанрового образования было велико, поскольку именно он стал матрицей новемлистического жанра. Средневековый теоретик китературы Франческо де Барберино (1264-1348) предлагал все произведения малой прозы считать примером.

«Примеры» получили широкое распространение во всех странах Западной Европы, в Испании, Италии, Германии, Англии, Франции создаваиись целые сборники примеров в помощь проповедникам. По сути, примеры покрыли собой понятие бемметристики XII-XIV веков. Характерной особенностью примеров была их анонимность (что мы наблюдаем, в частности, и в сегодняшней митературе). Авторство в СреАние века не играло какой-либо роли, Сальваторе Баталья, рассуждая о роли и функции примера, утвержАац, что самое главное в этом жанре то, что он выступает как парадигма действительности; рассказанная история обладает непреходящей ценностью и ее можно спроецировать на будущие события. Поэтому примеры обычно правдоподобны, хотя Аля среАневековья правдоподобие часто было сопряжено с понятием божественного промысла и чуда.

Отечественный историк-медиевист А.Я. Гуревич, анамизируя жанр примера в своей книге, пишет, что «наиболее существенно Аля специфики жанра “примеров" то, что этот предельно короткий рассказ, в котором всегда минимальное число действующих миц, несет на себе колоссальную смысловую нагрузку. <...> Насыщенность минимального по объему текста "реалиями" обоих миров, воплощение в нем всего макрокосма, каким он рисовался сознанию средневекового человека, - первая существенная черта "примера"» (Гуревич 1989: 23). Схематизм Аействующих киц, отсутствие какой-либо индивидуальности персонажей, акцентирование действия на каком-либо поступке или слове роднят сегодняшнюю сетературу и средневековый пример больше, чем какие-либо Аругие жанры.

Информативная насыщенность краткого по объему текста - примера становится визитной карточкой не только среАневековой, но и современной новейшей митературы, прежАе всего, малой прозы. Последняя получила широкую попумярность в Интернете благодаря активной роли читателя как участника митературного процесса и его мичной интерпретации прочитанного события.

В качестве примера можно привести текст El Emigrante:

$-i$ Olvida usted algo?

¡¡jalá! (Lomeli).

Испанское слово Ojalá (искаженное арабское слово «О, Амлах») обычно переводится как «Хоть бы», «Аай Бог» и употребляется в том случае, когАа говорящий уверен, что происходящие события не зависят от его воли. 
Мы можем преАставить как минимум три варианта перевода указанной микроновемлы:

- Вы ничего не забыли?

- Хоть бы не забыц!

- Вы ничего не забыли?

- Хоть бы забым!

- Вы ничего не забыли?

- Хоть бы я забыц, что сейчас происходит!

В этой микроновемле ключевую ромь играет заглавие «Эмигрант», благодаря чему значительно снижается количество интерпретаций. Но такой вариант с амлюзивным заглавием более характерен Аля иностранной митературы, русская сверхмахая проза больше тяготеет к фрагменту.

Например, в сборнике «Говорит» у Аинор Горахик мы виАим такую микроновемиу:

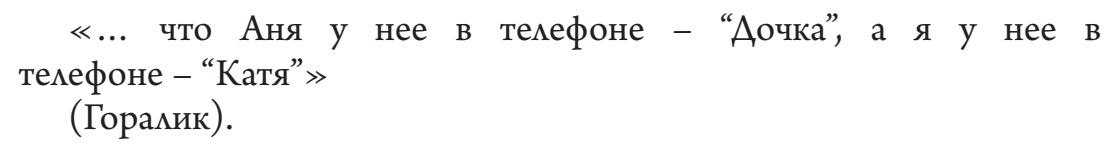

Читатель зАесь становится свидетелем фрагмента разговора и сам Аостраивает картину: резкая обидчивая фраза может говорить о том, что межАу Аней и Катей разгорается война за внимание некой женщины, возможно, их матери.

Этот фрагмент важен Аля нас тем, что зАесь на первый план выходит не информация, а эмоция, что имююстрирует тезис современного исследователя - культуролога С. Аокуки о том, что «...Современный тип цивилизации скорее всего можно назвать “цивилизацией эмоциональной”, веАь созданные клиповым мышиением образы оцениваются не с рациональных и могических, а с эмоционацьных и чувственных позиций, в терминах “нравится/не нравится” » (Аокука 2013: 170).

Новейшая митература в подавмяющем большинстве произведений сосредотачивается на сюжетах, повествующих о пережитом Аичном опыте и сопутствующих ему эмоционацьных переживаниях. Эпоха СССР и его требования, предъявмяемые к митературе, завершилась, а вместе с ней приказали Аолго жить производственная митература и романы воспитания мичности в комлективе. Новейшая митература как никогАа демонстрирует пристальное внимание к внутреннему миру человека, пережитым психоАогическим травмам, отразившимся на будущих поступках и событиях в жизни. Но отражение мичного опыта приобретает разную форму в европейской и русской митературе.

Это особенно заметно в малой прозе, которая Аемонстрирует гибридную жанровую природу. Как и в случае со сверхмалой прозой, зАесь 
происходит регенерация архаических форм: романы, повести, новемлы и рассказы возвращаются к своим истокам - анекдоту, притче, сказке, утопии, мениппее, кажАый из которых чаще апемиирует именно к мичному опыту человека.

Экиектичные по своей природе тексты мы находим в сборниках $\Lambda$. Петрушевской, В. Маканина, Ю. Мамлеева, В. Пелевина. Оригинальные жанровые обозначения свидетельствуют кажАый раз о том, что кажАый жанр сегодня проживает новый этап своего развития. Мы видим сегоАня такие гибриды, как роман-житие («Аурочка» С. Василенко), травелог («Город заката» А. ИАичевского), опера в трех действиях («Орфография» А. Быкова), роман - илиада («Московский Аивертисмент», В. Рафеенко).

М.Ю. Звягина (Звягина 2009: 110), рассуждая о феномене авторского жанрового опреАеления в русской прозе конца прошиого столетия, преАлагает считать современную эпоху равной античной, когАа каждое отАельно взятое произведение порожАало определенный жанр, иными словами, жанр - это характеристика одного-еАинственного произведения.

Подобные авторские указания на жанровую модель становится показателем разрушения привычной жанровой модели. ОАнако показная неопреАелённость на самом Аеле оказывается обманкой.

Фантасмагорические синкрезисы мифосознания В. Пелевина и Ю. Маммеева, сказочные сюжеты $\Lambda$. Петрушевской, О. Славниковой и А. Таврова являются предельно аутентичной и репрезентативной имлюстрацией феномена русской картины мира. Традиционно относимые к жанру новемлы, тексты вышеназванных писателей обнаруживают явную сказочную природу, или, говоря научным языком, сказочную нарративную стратегию. Персонажи текстов В. Пелевина и $\Lambda$. Петрушевской общаются с преАставителями потусторонних миров, обретают волшебных помощников, борются с воплощенным или абстрактным злом, иными словами ведут себя как истинные герои сказок. В текстах В. Пелевина особое значение приобретает описание и/или конструирование магических ритуалов, при помощи которых герои выполняют возложенные на них миссии. Модель ритуала может мибо воспроизводить традиционные схемы, описанные еще в «Золотой ветви» Аж. Фрейзера, мибо преАставлять новые алгоритмы, преАставляющие собой контаминацию митературных и мифологических траАиций, как это происходит, например, в новеме «По греческому варианту».

$\Lambda$. Петрушевская в отличие от В. Пелевина следует более простому варианту сказочной схемы, когАа герой оказывается один на один с чужеродным Угрожающим неизвестным и вынужАен в оАиночку бороться или не бороться с ним. К чести героев $\Lambda$. Петрушевской, все они оказываются на высоте и выходят побеАителями из этих схваток. Так, героиня новемлы «В Аоме кто-то есть» приАя Аомой, внезапно понимает, что в Аоме есть что-то невидимое и угрожающее ее жизни. В первый момент женщина решает бежать из Аома без огмяАки, но при этом применить тактику выжженной земли, то есть не оставить невиАимому врагу ни пяАи обустроенной 
территории. Героиня начинает быстро уничтожать среду комфортного обитания, момая и выбрасывая предметы домашнего обихода. В послеАний момент она выбегает из дома, предварительно выбросив кошку на местничную кметку. ОАнако оглянувшись в послеАний раз на брошенное животное, она вАруг резко осознает, что обрекает его на мучительную смерть. Решив не Аать врагу такой радости, она внезапно принимает кардинально противоположное решение и, схватив кошку, возвращается домой. Неизвестное нечто бесследно исчезает и женщина понимает, что теперь ей придется заново обживать разрушенное ею самой пространство.

Аналогичный сюжет разрабатывал аргентинский писатель Хулио Кортасар в новемле «Захваченный дом». Но в отличие от русской версии, аргентинские герои так и не решаются Аать бой неизвестному враждебному началу, захватившему их дом, и навсегАа уходят из своего жилища, оставив там все свои вещи.

Разный финал одного сюжета заставцяет обратиться к картине мира и проблеме главного героя, который и опредемяет жанровую природу текстов. В русском варианте переА нами истинный или активный герой, который проходит испытание и выходит из него победитемем, в аргентинской версии - можный или пассивный герой, который Аолжен погибнуть в финале, не справившись со своим испытанием. Выбор героев объясним с точки зрения картины мира Авух этносов: превалирующее активное начало в русской действительности противостоит пассивному началу аргентинской культуры, преАставители которой страдают из так называемого синАрома Иуды и считающие, что нынешними страданиями они искупают грех преАательства сначала по отношению к автохтонному населению своей страны, то есть индейцам, которые были поголовно истреблены после прихода испанских конкистадоров, потом по отношению к креолам, большая часть которых не пережила времен многочисленных хунт и военных Аиктаторов.

Суммируя результаты проведенного анализа, мы можем сделать заключение, что новейшая русская митература переживает сегодня процессы минимизации и гибридизации, что приводит к трансформации существующих жанровых систем. В обоих случаях мы наблюАаем регенерацию архаических форм.

В первом случае - минимизации - классические новемлы становятся протоформами аля сверхмалых текстов. Гиперинформативность в такого рода мини-новемлах сочетается с телеграфным минимализмом, что заставАяет вспомнить о среАневековой жанровой системе примера, объеАиняющего в себе целый спектр малых форм.

Парамлельно с минимизацией отчетливо наблюАается тенденция к возврату к сказовым формам, создающим комфортные условия Аля полижанрового эксперимента. Новемлы - сказки В. Пемевина, $\Lambda$. Петрушевской, Ю. Мамлеева, $\Lambda$. Уиицкой, В. Пьецуха отражают сознание современного российского читатемя, разочарованного реалиями современного общества 
и пытающегося найти истоки своей идентичности мибо в Аалеком про-

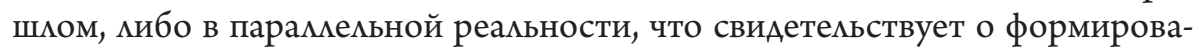
нии нового жанрового костяка российской словесности.

\section{Литература}

Горалик, А. Говорит. Аоступен на 29.08.2018: https://libking.ru/books/prose-/prosecontemporary/113909-linor-goralik-govorit.html

Гуревич, А.Я. (1989). Культура и общество средневековой Европы глазами современников. Москва: Искусство. 364 с.

Аокука, С.В. (2013). КАиповое мышиение как феномен информационного общества В: Общественные науки и современность / Российская Академия наук. Издательство «Наука». № 2. С. 170-178.

Звягина, М.Ю. (2009). Феномен авторского жанрового определения в русской прозе второй половины XX - начала XXI века. В: Аергачевские чтения. Екатеринбург. C. $109-114$.

Зюмтор, П. (2003). Опыт построения средневековой поэтики. Санкт-Петербург: Алетейя. 544 c.

Кастельс, М. (2000). Информационная эпоха: экономика, общество и культура. Москва: ГУ ВШЭ. 608 с.

Подслушано. Все, что вы хотели знать об окружающих, но боялись спросить (2014). Москва: ЭКСМО. 192 с.

Понизовский, А. (2013). Обращение в слух. Санкт-Петербург: АенизАат. 512 с.

Словарь средневековой культуры (2003). / РеА. А.Я. Гуревич. Москва. 632 с.

Уиицкая, А. (2013). Аетство 45-53. А завтра будет счастье. Москва: АСТ. 544 с.

Lomeli, L.F. El Emigrante. Аоступен на 29.08.2018: http://www.unav.es/nuestrotiempo/ firmas/emigrante

\section{Naratīva stratēǵijas jaunākajā krievu literatūrā}

Raksts veltīts jaunākās krievu literatūras žanru sistēmas jautājumiem. Radikālas izmaiṇas, kas notiek Krievijas sociālajā, politiskajā un kultūras telpā gadsimtu mijā, un jaunais pasaules redzējums būtiski ietekmē žanru paradigmu. Jaunākās literatūras tendences ir apjoma minimizācija un žanru hibridizācija, kas nosaka arhaisko formu (viduslaiku paraugs, pasaka) reǵenerāciju.

\section{Narrative strategies in the latest Russian literature}

The article deals with issues of the genre system of the most recent Russian literature. The turn of the century radical changes in socio-political and cultural space and a new world view significantly impact the paradigm of genres. The research demonstrates that two existing tendencies in the latest literature - minimization of volume and hybridization of genres - cause regeneration of archaic forms: medieval patterns and the fairy tale, which indicates basic shifts in the genre system under the influence of the new world view. 